\title{
The Evolution of Mating Systems in Acrocephalus Warblers
}

\author{
Clive K. CATchpole \\ School of Biological Sciences, Royal Holloway, University of Lonaon, \\ Egham, Surrey TW20 OEX, U. K.
}

\begin{abstract}
This paper reviews the mating systems of Acrocephalus warblers, and their probable evolution. Polygamy is seen as a gradual departure from the usual avian mating system of monogamy and biparental care. The main constraints are imposed by the environment, but due to high productivity the environmental potential for polygamy occurs at marshland ecotones. In such conditions, polygyny, polyandry and promiscuity have been found to occur in varying degrees. DNA fingerprinting is now clarifying the distinction between social mating systems and realised genetic reproductive success. Morphological adaptations, such as bill size and testes size, can also be correlated with different mating systems. There is also a clear correlation between mating systems, the resulting sexual selection pressure and the structure and function of song. Monogamous species produce long, complex songs for mate attraction, and polygamous species produce shorter, simpler songs for territorial defence. Polygamous species also have separate longer songs for mate attraction, and shorter songs for territorial defence and mate guarding.
\end{abstract}

Key Words : Acrocephalus, Mating system, Polygamy, Song

The main objective of this paper is to consider the evolution of mating systems in Acrocephalus warblers. Mating systems generally describe how mating takes place, how mates are obtained, how many of each sex, the characteristics of the pair-bond, and the pattern of parental care by each sex. In his major review, LACK (1968) found that monogamy was the main form of mating system in birds. In passerine birds, it is found particularly among insectivorous species, such as warblers. LACK (1968) suggested that the reason for this was that insects are hard to find, and that both parents are needed to feed the young. He also suggested that monogamy evolved within the ecological constraint of a clutch size adjusted to the maximum number of young two parents can feed. LACK (1968) therefore viewed monogamy as advantageous to both sexes, as if either sex deserts it will pay the huge cost of half or even more of its reproductive success through starvation of the young. Monogamy and biparental care are therefore more likely to evolve together.

Since the important paper by TRIVERS (1972), it has become accepted that although both male and female will be selected to maximize their reproductive success, this may lead to conflict rather than cooperation between the sexes. The influential paper by EMLEN \& ORING (1977) for the first time viewed mating systems as the result of individuals competing to maximize their reproductive success. They emphasised the importance of sexual selection and parental care as well as ecology in understanding the evolution of mating systems. To maximize their reproductive success, females need one or few matings, and their reproductive 
success is far more limited by access to resources than to males. Males however, can potentially fertilize many females, and their reproductive success is more limited by access to females.

The problem with birds is that, as males in some species provide parental care, males also become a resource important for female reproductive success. Biparental care and monogamy are found in most bird species, and it is tempting to regard these as the ancestral state. But the prevalence of monogamy may not be due as LACK (1968) suggested, to the mutual advantage of the two sexes. Indeed, there are strong theoretical reasons for expecting males to desert females and attempt polygyny (e. g. MAYNARD SMITH 1977). Even if male desertion reduces nestling productivity, unlike the female he can easily compensate by mating with more and more partners. Therefore in most bird species, males desert females and polygyny is more common than polyandry.

It may be that there are constraints which act upon some species more than others and prevent them from departing from monogamy. In particular EMLEN \& ORING (1977) saw the environment as a major constraint, limiting or encouraging the evolution of different types of mating system. They suggested that 'ecologic al constraints impose limits on the degree to which sexual selection can operate.' In birds, the 'environmental potential' for polygyny only occurs when females or the resources they require can be economically defended by males.

When males contribute little or no parental care females suffer no cost from polygyny, but such cases are rare in passerine birds. In general, it has been assumed that females do pay a cost by sharing a male, but that in some cases they may be compensated by gaining access to higher quality resources or mates. The polygyny threshold model (VERNER \& WiLlson 1966, ORIANS 1969) was an attempt to explain this, and has been extremely influential. Another compensation model is the 'sexy son hypothesis' developed by WEATHERHEAD \& ROBERTSON (1979), suggesting that females may benefit by their sons inheritance of attractive sexually selected traits. An important alternative to compensation models, are those which assume that females must accept the cost without compensation, such as the deception hypothesis proposed by Alatalo et al. (1981). These and various other alternative hypotheses have been placed into hierachical classification by $\mathrm{S}$ EARCY \& YASUKAWA (1989). More recently, BENSCH \& HASSELQUIST (1991) have emphasised the importance of predation in any compensation models. The Great Reed Warbler shows considerable variation in the degree of polygyny, probably as the result of different environmental factors across a wide geographical range.

In this paper, the comparative approach will be used to investigate the evolution of mating systems in Acrocephalus warblers. This was attempted quite recently by LEISLER \& CATCHPOLE (1992). However, since then there has been quite rapid progress in several areas, for example in DNA fingerprinting and sperm competition in birds (BIRKHEAD \& MøLLER 1992). The important distinction between genetic and social monogamy has significant implications for the classification of mating systems used by LEISLER \& CATCHPOLE (1992). In particular, the recent DNA fingerprinting study of the Aquatic Warbler Acrocephalus paludicola (SCHULzE-HAGEN et al. 1993) has caused considerable interest and speculation (see BIRKheAD 1993). The Seychelles Warbler Acrocephalus sechellensis is also unusual, in that it is a cooperative breeder whose mating system has recently been investigated by KOMDEUR (1992). Finally, the evolution of song in Acrocephalus warblers 
has been closely linked to their mating systems (CATCHPOLE 1980, 1987), and this paper will also review more recent studies on the structure and function of song.

\section{METHODS}

The classification of mating systems which form the basis of this paper are as follows :

1. Monogamy. One male mates with one female.

2. Polygamy. One individual of one sex mates with several of the other sex.

2a Polygyny. One male mates with several females.

2b Polyandry. One female mates with several males.

2c Promiscuity. Males and females mate with several of the other sex.

The methods for the section on mating systems are based upon those in LEISLER \& CATCHPOLE (1992), where further details can be found. Only additional references after this date are added to the bibliography. The main species studied are six central European reed warblers : the Great Reed Warbler Acrocephalus arundinaceus (also studied in Japan), the Reed Warbler Acrocephalus scirpaceus, the Marsh Warbler Acrocephalus palustris, the Moustached Warbler Acrocephalus melanopogon, the Sedge Warbler Acrocephalus schoenobaenus, and the Aquatic Warbler Acrocephalus paludicola. The other species considered is the Seychelles Warbler Acrocephalus sechellensis, and further details on methods can be found in Komdeur (1992) and CATCHPOLE \& Komdeur (1993).

\section{RESULTS}

1) The mating systems of Acrocephalus warblers

The mating systems of Acrocephalus warblers are set out in Table 1. These are ranked, so that the species which depart least from monogamy are at the bottom, and those which depart most are at the top. The table is based upon some data in LEISLER \& CATCHPOLE (1992), but since then there have been several changes in both the reported frequency of social polygyny and on the frequency of extra-pair fertilizationz (EPF\%). Both of these are now included in Table 1. Also now included is the Seychelles Warbler recently studied by KomDeUn (1992). The mating system is monogamous, but highly unusual in that cooperative breeding also occurs with the young remaining to help parents raise the single chick.

The position of the three monogamous European species at the bottom remains much the same. Whole populations in Europe have been found to be monogamous, although there are isolated cases of social polygyny and unsuccessful attempts at polyterritorial polygyny. DUCKWORTH (1992) recently reported that $4 \%$ of an English Reed Warber population were polygynous. As yet there are no DNA fingerprinting studies to report on these species. Where whole populations have been found to be monogamous, and monogamy seems to be the social norm, it seems reasonable to retain the term monogamy to describe the mating system. However, the incidence of both social polygamy and EPFs should always be noted, and are now included in Table 1.

In the Sedge Warbler there has now been a significant advance with the recent study of LANGEFORS \& HASSELquisT (1993) on a population in Sweden. Although this species was previously classified as monogamous by LEISLER \& CATCHPOLE 
Table 1. Mating Systems of Acrocephalus Warblers.

\begin{tabular}{llcc}
\hline \multicolumn{1}{c}{ Species } & Mating System & $\begin{array}{c}\text { Polygyny } \\
(\%)\end{array}$ & $\begin{array}{c}\text { EPF } \\
(\%)\end{array}$ \\
\hline paludicola & Polygamous-promiscuous & - & 36 \\
arundinaceus & Polygamous-polygynous & $10-80$ & 3 \\
schoenobaenus & Monogamous & $0-20$ & 8 \\
palustris & Monogamous & $0-7$ & - \\
scipaceus & Monogamous & $0-4$ & - \\
melanopogon & Monogamous & 0 & - \\
sechellensis & Monogamous-cooperative & 0 & - \\
\hline
\end{tabular}

(1992), they noted that in many ways it had the most potential to develop polygyny. LANGEFORS \& HASSELQUIST (1993) have now found that on average 20\% of males are polygynous, and $17 \%$ of females sequentially polyandrous. DNA fingerprinting showed that $8 \%$ of young were the result of EPFs. EPFs were all sired by close neighbours, and occurred in broods with both monogamous and polygamous parents.

In the case of the polygynous Great Reed Warbler, there has been a small but interesting change. A DNA fingerprinting study by Hasselquist et al. (1995) has shown that only $3 \%$ of young are the result of EPFs. The same male sired all the EPF young in any one brood, and all were near neighbours. Overall, the results show a remarkably low frequency of extra-pair paternity. It seems that in the Great Reed Warbler, social polygyny is still the main way in which males enhance their fitness.

In the case of the Aquatic Warbler, the situation is quite different. LEISLER \& CATChPOLE (1992) classified this species as polygamous, as previous studies had suggested that the mating system was rather unusual. Studies by DyRCZ (1989) and DYRCZ \& ZDUNEK (1993) have shown how the lack of male investment in freeding or incubation, and the difficulty of observing these elusive birds, make it difficult to obtain reliable data on the fine details of the mating system. In a very recent paper, SCHULZE-HAGEN et al. (1993) have at last revealed that the situation is even more complex than previously suspected. DNA fingerprinting revealed that the rate of EPFs was $36 \%$, one of the highest reported for any passerine. In small broods of 2-4 nestlings, the young had only one father, but in larger broods of 5-6, the nestlings were fathered by $2-4$ different males. This multiple paternity suggests that the aquatic warbler has a very different type of mating system, which although certainly polygamous is also promiscuous.

2) The environmental potential

European Acrocephalus species inhabit marshland, and as emphasised by LEISLER \& CATCHPOLE (1992) the two polygamous species occur at either end of the marshland gradient, at the ecotones. As pointed out by LEISLER \& CATCHPOLE (1992) there are a number of reasons why these ecotones provide the environmental potential for the evolution of polygamy. The sparse vegetation profile lets in more light to generate higher primary productivity resulting in a higher invertebrate biomass. Ecological studies show that not only are there more insects, but more large insects become available. Large insects are more profitable prey, and by 
specialising on these females are more likely to be able to feed their young without male help. Thus, one of the major constraints to the evolution of polygyny is removed. Females are more likely to reduce the costs of male desertion, and polygyny is more likely to evolve.

LEISLER \& CATCHPOLE (1992) produced a variety of evidence to suggest that the two polygyamous species exploit this environmental potential. They defend large resource-based territories, take large prey and are of ten single prey loaders. These factors combine to significantly reduce such optimal foraging parameters as travel time, search time and handling time.

In contrast, the monogamous species defend small territories and of ten fly large distances to find food. They take small prey and are multiple prey loaders. The Seychelles Warbler is similar, and small insects are difficult to locate in their dark forest habitat. Helpers are even needed in order to raise one chick successfully (KOMDEUR 1992). Raising a chick successfully also depends crucially upon the abundance of insect food. Only males who held high quality territory were able to raise chicks successfully. KOMDEUR (1992) also directly tested the hypothesis that habitat quality was the main constraint imposing delayed and cooperative breeding. He removed the constraint by translocating birds to a new island where high quality territories were empty and waiting. As predicted, young birds did not become helpers and started breeding immediately.

\section{3) Parental care}

The relative amount of parental care each sex invests in incubation and feeding young is shown in Table 2, where the species are placed in the same rank order of mating system. In the cooperatively breeding Seychelles Warbler there is biparental care, but as we have seen additional helpers are of ten necessary to raise one chick successfully. The next three monogamous species all show the same pattern of biparental care. It is tempting to conclude that the ecological constraint imposed by feeding upon smaller insect prey may have trapped these males into investing equally in parental care, just as a similar constraint trapped the Seychelles Warbler into delayed and cooperative breeding. A more indirect way to test this is by mate removal experiments, to see whether the female pays a cost. Duckworth (1992) working in English used Reed Warblers to do this. He removed male Reed Warblers and found that there were no effects upon the success of incubation. However females had to increase their feeding rate, and late season broods (when food is more scarce) were unsuccessful due to starvation of the young. This suggests that biparental care is needed in a monogamous species like the Reed Warbler.

Table 2. Mating Systems and Parental Care in Acrocephalus Warblers.

\begin{tabular}{llll}
\hline \hline Species & Mating System & Incubation & Feeding Young \\
\hline paludicola & polygamous & female only & female only \\
arundinaceus & polygamous & female only & shared \\
schoenobaenus & monogamous & mainly female & shared \\
palustris & monogamous & shared & shared \\
scipaceus & monogamous & shared & shared \\
melanopogon & monogamous & shared & shared \\
sechellensis & monogamous & shared & shared \\
\hline
\end{tabular}


The Sedge Warbler, which departs more from monogamy than others, shows some evidence of less male investment. Several studies have suggested that males incubate less than females. LEISLER \& CATCHPOLE (1992) also found that in the various ecological measures of territory and prey size, this species was closer than the others to the polygamous species. In terms of both environment and parental care, the Sedge Warbler seems the most likely of the 'monogamous' group to have populations where polygamy will evolve. The recent findings of LANGEFoRs \& HASSELQUIST (1993) appear to confirm this prediction.

The polygynous Great Reed Warbler appears to be one step further, as the male is comletely emancipated from incubation. He therefore has considerable time in which to readvertise for further females. Although the male is said to share in feeding, in polygynous males the feeding must be shared among the females. This usually results in the first female receiving the major share of feeding help, and only the secondary females pay a significant cost.

The gradual trend of male emancipation from biparental care continues with the Aquatic Warbler. Work by DyRcz (1993) has now confirmed that only the female incubates, broods and feeds the nestlings. There is thus a complete trend in Acrocephalus warblers, from biparental care to uniparental care, with males emancipated to become polygynous. The male Aquatic Warbler is completely free to continue to advertise and mate with other females, and does as the DNA fingerprinting results confirm (SchUlzE-HAGEN et al. 1993). But such total emancipation appears to have a hidden cost, as the same study revealed that females also mate with other males, thus reducing the potential reproductive success of the first male.

\section{4) Correlations with morphology}

So far we have dealt with behavioural and ecological correlations with mating systems, but there are also morphological correlations to consider. Measurements of bill proportions (LEISLER \& CATCHPOLE 1992) have already shown that the two polygamous species have by far the largest bills, and therefore have the main morphological adaptation for exploiting the larger prey found in the marshland ecotones. But there are also anatomical correlations between the reproductive system and mating system.

We have already seen that extra-pair copulations occur in all the Acrocephalus species where DNA fingerprinting has been applied. This suggests that sperm competition (BIRKHEAD \& MøLLER 1992) is widespread, and indeed mate guarding has also been observed in all species. Mate guarding seems to pose problems for the promiscuous Aquatic Warbler, as multiple paternity is quite common. It seems that females can easily elude males in the dense vegetation, making conventional mate guarding difficult. Detailed observations by SCHULZE-HAGEN et al. (1995) have revealed a most unusual type of mate guarding in this species. When copulaying, most Acrocephalus species take only a few seconds. The male Aquatic Warbler behaves more like an insect or amphibian in copulation, by clinging to the female for 25 minutes on average, and making multiple inseminations. This may be a form of contact mate guarding, but is more likely to be an attempt to flood the females reproductive tract with sperm (BIRKHEAD 1993). This would swamp the sperm of other males, and sperm may also remain in any sperm storage areas of the female reproductive tract to fertilize later eggs. 
Table 3. Mating Systems and Song Structure in Acrocephalus Warblers.

\begin{tabular}{llll}
\hline \hline Species & Mating System & Song Length & Repertoire \\
\hline paludicola & Polygamous & short-discrete & Medium \\
arundinaceus & Polygamous & short-discrete & Medium \\
schoenobaenus & Monogamous & long-discrete & Medium \\
palustris & Monogamous & continuous & Large \\
scipaceus & Monogamous & continuous & Large \\
melanopogon & Monogamous & continuous & Large \\
sechellensis & Monogamous & short-discrete & Medium \\
\hline
\end{tabular}

The extended copulation seems to occur during the maximum female fertile period (dawn and dusk) to ensure fertilization of the next egg to be laid. ScHulze -HAGEN et al. (1995) have now found anatomical correlations with this behaviour. The male Aquatic Warbler has much larger testes than any other Acrocephalus species, a large cloacal protuberance which may act as a sperm store, and have vast numbers of sperm in their seminal glomera. There are thus very clear anatomical correlations with the unusual mating system in the Aquatic Warbler.

\section{5) Correlations with song}

CATCHPOLE (1980) pointed out that there was a clear correlation between mating system and song structure in European Acrocephalus warblers. This general pattern can be seen in Table 3 , where the species are arranged in the same order as previous tables. The monogamous species have long, continuous songs, which either stop or reduce after pairing. The polygamous species have short, discrete songs, and continue to sing after pairing. This basic difference can be seen particularly well in the Aquatic Warbler and Sedge Warbler (Fig. 1). There is also a similar trend in syllable repertoire size, in general the monogamous species have larger repertoires than the polygamous species.

CATCHPOLE (1980) suggested that the longer, more complex songs in the monogamous species were used in sexual attraction, and had evolved by female choice and intersexual selection. The shorter, simpler songs of the polygamous species were used in male-male territorial behaviour, and had evolved largely by intrasexual selection. Since then, a considerable number of laboratory and field studies have confirmed these basic predictions. In monogamous species there is biparental care, so females need to choose a high quality male to help her feed the young. She will select for male quality more than territory quality, and one obvious indicator may be the quality of male song. This may explain the evolution of long and elaborate songs used to attract females. In polygamous species, a female is often deserted and may have to raise the young alone. She should therefore select for territory quality more than male quality. There is no direct selection for elaborate songs, and males evolve short, simple songs used in territorial defence.

In the monogamous Sedge Warbler, CATCHPOLE (1980) showed that in the field, males with larger repertoires attracted females earlier than their rivals. In the laboratory, CATCHPOLE et al. (1984) also showed that a range of recordings from this population had a differential effect upon captive females implanted with oestradiol. A further test with an artificial song confirmed the effect upon captive 


\section{Aquatic}
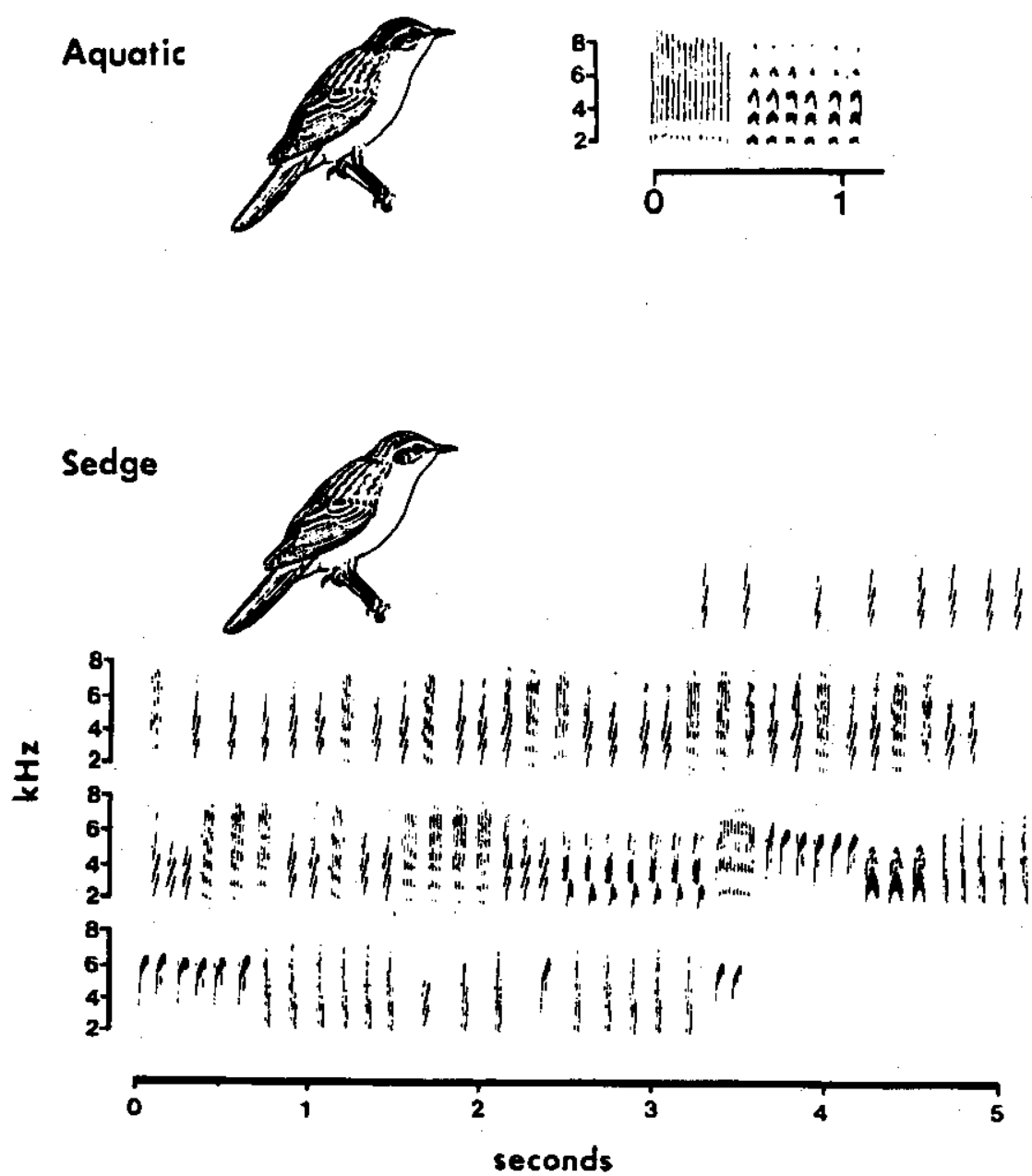

Fig. 1. Sonagrams showing the shorter, simpler song of the polygamous Aquatic Warbler A. paludicola, and the longer, more complex song of the monogamous Sedge Warbler A. schoenobaenus. (From CatchPole 1987).

females, but there was no effect upon males in the wild (CATChPOLE 1989). The only other experimental study on a monogamous species is a very recent one by $F$ ESSL \& HoI (1993) on the Moustached Warbler. They conclude that the long, elaborate song is used in female attraction, but that a short, whistled introduction may be used against rival males. This is a trend which becomes much more marked in the two polygamous species.

Quite early on CATCHPOLE (1983) established that the song structure in the polygamous Great Reed Warbler was more complex and variable than previously suspected. Males produced two types of song, short and long (Fig. 2). Long songs are given by the unpaired male and used for female attraction. CATCHPOLE (1986) showed that in the field males with larger repertoies had higher reproductive success, and in the laboratory CATCHPOLE et al. (1986) showed that females responded more to larger repertoires. HASSELQUIST \& BENSCH (1991) have 


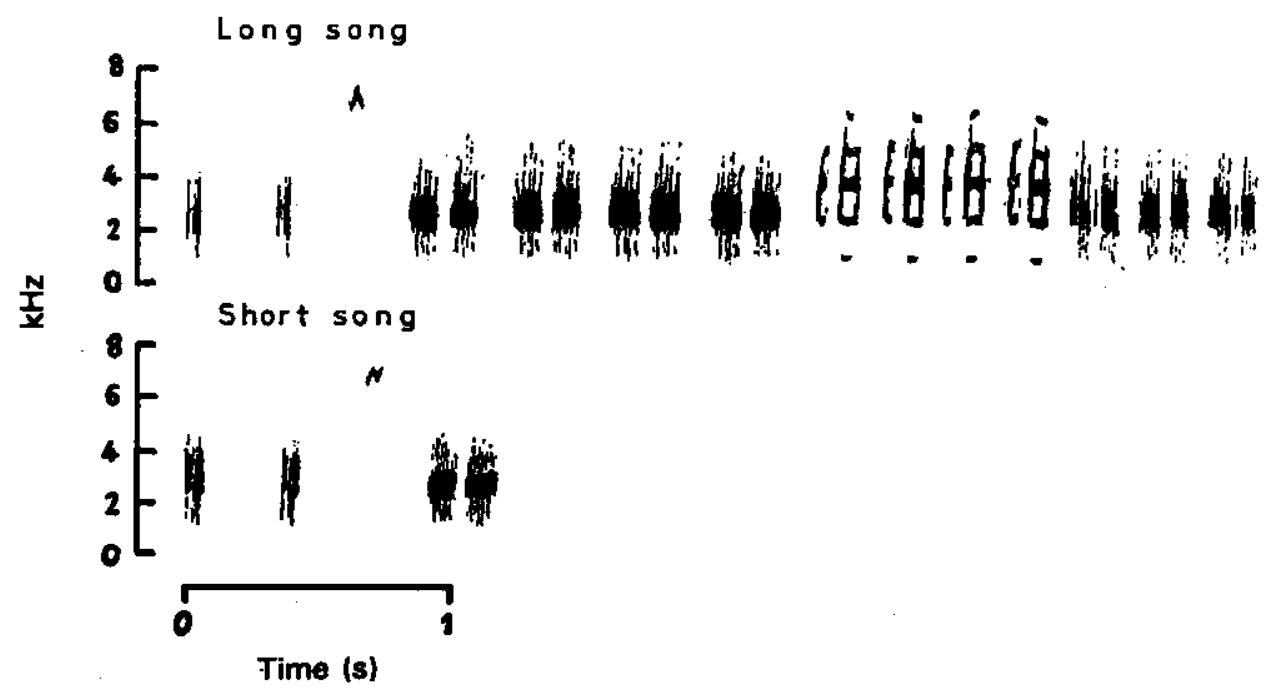

Fig. 2. Sonagrams showing the long and short songs of the Great Reed Warbler A. arundinaceus. (From CATChPOLE 1983).

confirmed the long and short song structure, and found that polygynous males make a trade-off between mate guarding their primary female and singing long songs to attract a secondary female.

BENSCH \& HASSELQUIST (1992) have now demonstrated active female choice in Great Reed Warblers, by radio tracking prospecting females. They showed that females visited the territories of several singing males before making a choice. In each case they selected males singing long songs. It would be interesting to know how the singing patterns and repertoires of these different males compared. In their DNA fingerprinting study, HASSELQUIST et al. (1995) found that males which obtained EPFs, had larger repertoires than their neighbours whom they cuckolded.

Returning to the short songs, CATCHPOLE (1983), found that these occurred in male-male interactions, whether natural or to playback. Males were much more reluctant to approach, and even retreated from playback of short songs. HASSELQUiST \& BENSCH (1991) emphasised the role of short songs in mate guarding, but CATCHPOLE (1983) found that short songs were also produced from unmated males in aggressive interactions. It seems that short songs are best interpreted as aggressive signals given in any male-male interaction, including mate guarding.

CATCHPOLE \& LeISLer (1989) found that the polygamous Aquatic Warbler had three different types of song (Fig. 3). Observations and playback experiments showed that the shorter, simpler A songs were used as a short range aggressive signal, and $\mathrm{B}$ songs as a more long range territorial proclamation. Type $\mathrm{C}$ songs were longer and more complex, and appeared to function in female attraction. DYRCZ \& ZDUNEK (1993) confirmed this pattern of use, and also found that unlike most other Acrocephalus species, Aquatic Warblers continue to sing throughout the long breeding season. Song occurred particularly at dusk and dawn, and like the pattern of copulation may be related to the maximum fertile period in females. Mate guarding may again be an important, but not exclusive function of the 


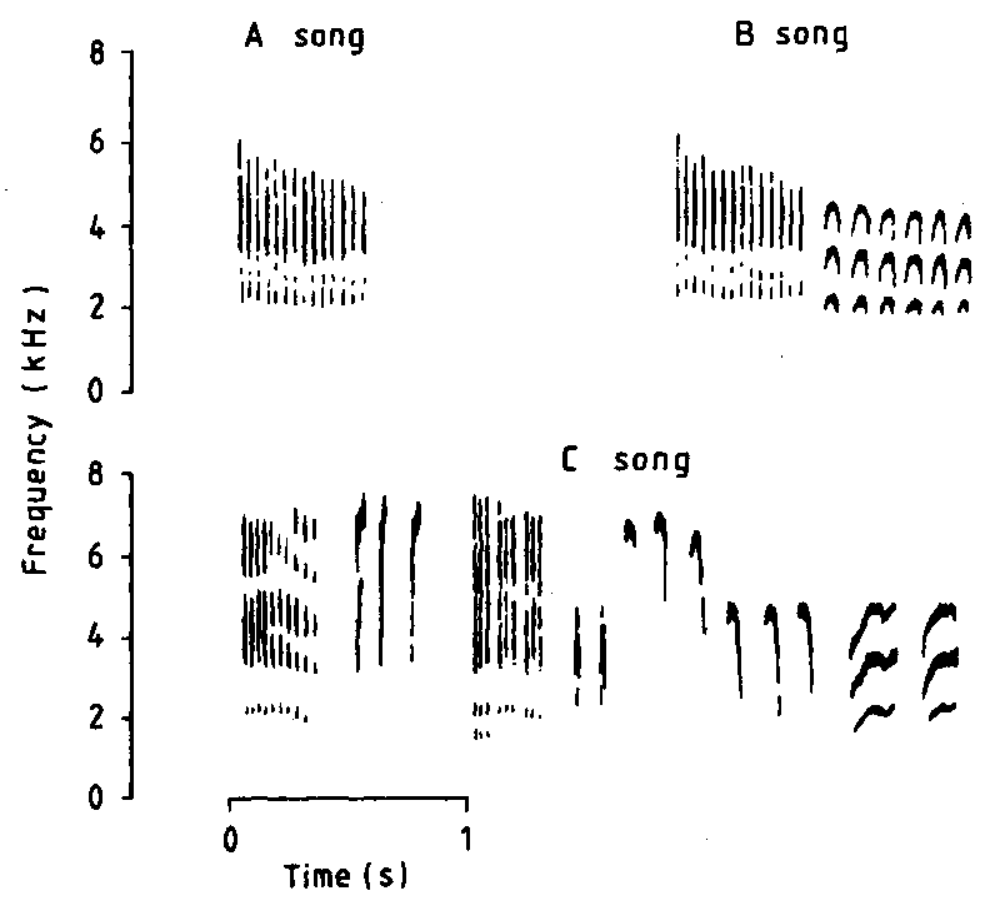

Fig. 3. Sonagrams showing the three different types of song in the Aquatic Warbler A. paludicola. (From CATCHPOLE \& LEISLER 1989).

shorter songs.

In both these polygamous species, the Acrocephalus pattern of long, complex songs for female attraction, and shorter simpler ones for repelling rival males is maintained, although separate song structures are used. In each case, song structure and the pattern of use seems finely tuned to the demands of the polygamous mating system. In these systems, territorial defence and female attraction are both important, and separate song structures have evolved for these different functions.

The Seychelles Warbler is an unusual Acrocephalus species, being a rate, island endemic with a cooperative breeding system (KoMDEUR 1992). It lives in a constant, tropical climate, is resident all year round, and breeds in a forest habitat. A recent study by CATCHPOLE \& KOMDEUR (1993) has shown that unlike European marshland species, the song is transmitted within the tropical forest frequency window, although this relationship may well be confounded by phylogeny. Unlike the European species, there is no pronounced seasonal peak of song activity. Breeding has two small, annual peaks, and these were correlated with an increase in song activity two months earlier, suggesting a sexual function. The songs are relatively short and simple, but not repeated and the considerable repertoire is cycled through more in the style of a monogamous species like the Sedge Warbler. This line of evidence suggests that there is some sexual function of song.

However, even in paired males, song continues throughout the year at a very low level, short bursts occurring in territorial disputes with neighbours. In playback 
experiments, all males responded with song, and some females and helpers sang too. These results suggest that song is an important part of territorial defence. This would be expected of a species which must maintain territory all year, and where a limited number of high quality territories are keenly contested. It may also help to explain the evolution of relatively short, simple songs in the Seychelles Warbler. Mate guarding may also be of particular importance in a species where a pair and helpers may only raise one chick at a time. Clearly, much more work is needed to relate song structure more precisely to function in the unusual social system of the Seychelles Warbler.

\section{DISCUSSION}

Since the earlier review of Acrocephalus mating systems by LEISLER \& CATChPole (1992) there have been several important developments. Perhaps the most significant is the impact which the technique of DNA fingerprinting has already made. The confirmation by DNA fingerprinting of the unusual promiscuous mating system in the Aquatic Warbler (ScHulze-HAGEN et al. 1993) is a particularly good example. The significance of such promiscuity, and in particular multiple paternity, has already generated considerable interest and speculation (see BIRKHEAD 1993). DNA fingerprinting has also revealed a surprising low EPF rate in the polygynous Great Reed Warbler (HASSELQUIST et al. 1995), and yet a higher rate in the monogamous Sedge Warbler (LANGEFoRS \& HASSELQUIST 1993). It seems clear that DNA fingerprinting is needed to provide accurate information about the real genetic reproductive success of each species, rather than the social and behavioural descriptions we have had to rely upon in the past. At the same time, we should also continue with careful observational field studies. For example, the significant degree of social polygamy in Sedge Warblers now reported from Sweden, has confirmed the earlier prediction from LEISLER \& CATCHPOLE (1992) that this 'monogamous' species has considerable potential to evolve polygamy.

The recent study by KomDEUR (1992) on the Seychelles Warbler has provided experimental support for the view that ecological constraints and environmental potential (EMLEN \& ORING 1977) are the key to understanding the evolution of different mating systems. The removal experiments by DUCKworTH (1992) could be extended to other species, particularly the Great Reed Warbler where different results are obtained in different geographical locations. We should not be surprised that this is so, as there may well be considerable variation in the environmental potential in different areas (SEARCY \& YASUKAWA 1989). DUNN \& ROBERTSON (1992) studied geographical variation in two populations of Tree Swallows which differed in food abundance. Although they found no no differences in the amount of polygyny between two areas, removal experiments showed that females deprived of male parental care produced fewer offspring in the area with less abundant food. There seems to be some evidence, from both removal and translocation experiments that environmental potential and constraints, particularly food supply, may be the key to the evolution of polygamy in insectivorous passerines.

Only when the environmental potential for polygamy is exploited and constraints are removed can males become emancipated from parental care. When this occurs, Acrocephalus warblers tend to depart from biparental care and monogamy, and 
become polygamous. This mainly leads to polygyny, but polyandry and even promiscuity can also develop. As we have also seen, there may even be anatomical adaptations, such as bill or testes size, associated with different mating systems.

The type of mating system which develops, then has a profound effect upon how different patterns of sexual selection shape the evolution of song. Females in polygynous systems are more likely to select males through the quality of their territories, and females in monogamous systems more likely to select the best males. But in both systems, males need to defend territories and attract females and in some cases may develop different songs for different functions. Therefore, although the original correlation between song structure and mating systems suggested by CATCHPOLE (1980) has proved to be quite robust, it was also too simple. Polygamous species do have shorter and simpler songs when compared to monogamous species. However, polygamous species also have separate long songs for mate attraction and shorter ones for territorial defence, which includes mate guarding their fertile females. There is thus a more complex relationship between song structure and mating system, which subtly reflects the different pressures exerted by sexual selection in each Acrocephalus species.

\section{REFERENCES}

Alatalo, R., Carlson, A., Lunberg, A. \& Ulfstrand, S., 1981. The conflict between male polygamy and female monogamy : the case of the Pied Flycatcher Ficedula hypoleuca: Amer. Natur. 117 : 738-753.

BENSCH, S. \& HASSELQUIST, D., 1991. Nest predation lowers the polygyny threshold : a new compensation model. Amer. Natur, $138: 1297-1306$.

BENSCH, S. \& HASSELQUIST, D., 1992. Evidence for active female choice in a polygynous warbler. Anim. Behav. $44: 301-311$.

BirkHEAD, T. R., 1993. Avian mating systems : the Aquatic Warbler is unique. Trends Ecol. Evol. $8: 390-391$.

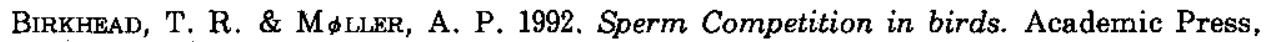
London.

CATChPOLE, C. K., 1980. Sexual selection and the evolution of complex songs among European warblers of the genus Acrocephalus. Behaviour 74:149-166.

CATCHPOLE, C. K., 1983. Variation in the song of the Great Reed Warbler Acrocephalus arundinaceus in relation to mate attraction and territorial defence. Anim. Behav. $31: 1217-1225$.

CATCHPOLE, C. K., 1986. Song repertoires and reproductive success in the Great Reed Warbler Acrocephalus arundinaceus. Behav. Ecol. Sociobiol. 19 : 439-445.

CATchpole, C. K., 1987. Bird song, sexual selection and female choice. Trends Ecol. Evol. 2 : 94-97.

CatChPole, C. K., 1989. Responses of male Sedge Warblers to playback of songs of different repertoire sizes. Anim. Behav. $37: 1046-1047$.

Catchpole, C. K., Dittam,, J. \& Leisler, B., 1984. Differential responses to male song repertoires in female songbirds implanted with oestradiol. Nature 312 : 563-564.

Catchpole, C. K. \& KomdeuR, J., 1993. The song of the Seychelles Warbler Acrocephalus sechellensis, an island endemic. Ibis $135: 190-195$.

CATCHPOLE, C. K. \& LetSLER, B., 1989. Variation in the song of the Aquatic Warbler Acrocephalus paludicola in response to playback of different song structures. Behaviour 108 : 125-138.

Catchpole, C. K., Lensler, B. \& Dittami, J., 1986. Sexual differences in the responses 
of captive Great Reed Warblers Acrocephalus arundinaceus to variation in song structure and repertoire size. Ethology $73: 69-77$.

DuckWoRTH, J. W., 1992. Effects of male removal on the behaviour and reproductive success of Reed Warblers Acrocephalus scirpaceus. Ibis 134 : 164-170.

DunN, P. O. \& RoBertson, R. J., 1992. Geographic variation in the importance of male parental care and mating systems in Tree Swallows. Behav. Ecol. 3 : 291-299.

Dyrcz, A., 1989. Polygyny in the Aquatic Warbler Acrocephalus paludicola. Ibis 131 : 298-300.

DYrcz, A., 1993. Nesting biology of the Aquatic Warbler Acrocephalus paludicola in the Biebrza marshes. Die Vogelwelt $114: 2-15$.

Dyrcz, A. \& ZDUnek, W., 1993. Breeding ecology of the Aquatic Warbler Acrocephalus paludicola on the Biebrza marshes, northeast Poland. Ibis 135 : 181-189.

EmLeN, S. T. \& ORING L. W., 1977. Ecology, sexual selection and the evolution of mating systems. Science $197: 215-223$.

EzaKI, Y., 1987. Male time budgets and recovery of singing rate after pairing in polygamous Great Reed Warblers. Jap. J. Ornithol. 36 : 1-11.

Fessi, B. \& HoI, H., 1993. The advantage of a two part song. Abstracts of 23rd International Ethological Conference. 44.

Hasseiquist, D. \& BENSCH, S., 1991. Trade-off between mate guarding and mate attraction in the polygynous Great Reed Warbler. Behav. Ecol. Sociobiol. 28:187193.

Hasseiquist, D., BENSCh, S. \& von SchanTz, T., 1995. Low frequency of extra-pair paternity in the polygynous Great Reed Warbler Acrocephalus arundinaceus. Behav. Ecol. 6 : $27-38$.

KOMDEUR, J. 1992., Importance of habitat saturation and territory quality for evolution of cooperative breeding in the Seychelles Warbler. $358: 493-495$.

LACK, D., 1968. Ecological adaptations for breeding in birds. Methuen, London.

LANGEFORS, A. \& HASSELQUIST, D., 1993. Mating system and extra-pair fertilization in the Sedge Warbler. Abstracts 23rd International Ethological Conference 74.

LEISLER, B\& CATCHPOLE, C. K., 1992. The evolution of polygamy in European reed warblers of the genus Acrocephalus: a comparative approach. Ethol. Ecol. Evol. $4: 225-243$.

Maynard Smith, J., 1977. Parental investment-a prospective analysis. Anim. Behav. 25 $: 1-9$.

OrIaNs, G. H., 1969. On the evolution of mating systems in birds and mammals. Amer. Natur. 103 : 589-603.

Schulze-Hagen, K., Leisler. B., Birkhead, T. R. \& Dyrcz, A., 1995. Prolonged copulation, sperm reserves and sperm competition in the Aquatic Warbler Acrophalus paludicola. Ibis 137 : 85-91.

SChULZE-HAGEN, K., SWATSChEK, I., DYrCZ, A. \& WinK, M., 1993. Multiple Vaterschaften in Bruten des Seggenrohrsangers Acrocephalus paludicola : Erste Ergebnisse des DNA-Fingerprintings. J. Orn. $134: 145-154$.

Searcy, W. \& Yasukawa, K., 1989. Alternative models of territorial polygyny in birds. Amer. Natur, 134 : 323-343.

Trivers, R. L., 1972. Parental investment and sexual selection. CAmpbell, B. (ed.) Sexual selection and the descent of man 1871-1971:136-179. Aldine, Chicago.

VERNER, J. \& WILISON, M. F., 1966. The influence of habitats on the mating systems of North American passerine birds. Ecology 47 : 143-147.

WEATHERHEAD, P. J. \& ROBERTSON, R. J., 1979. Offspring quality and the polygyny threshold : the 'sexy son hypothesis.' Amer. Natur. 113:201-208. 
年度を越えて同じ繁殖場所へ戻ってきた成鳥の割合は、雄で55\%、雌で51\%と高かった（Table 1)。 調查地で巣立った雛で、翌年繁殖のために戻ってきたあのの割合も高かった (14\%; Table 1)。あ る年度に繁殖に失敗した個体と成功した個体とで、翌年の帰還率に違いはなかった（Table 1)。每 年の繁殖個体の約 $50 \%$ は、調查地外で巣立ったものだった（Table 2)。平均寿命は雌雄とも 3 年だっ た (Fig. 1 参照)。調查地で生れ調査地に定着した個体と他所で生れて移入してきた個体とで、寿 命に差はなかった。代替繁殖戦略（つがい外交尾や種内托卵）の効果は低かったー1987-1991年に巣 立った雊の $95 \%$ 以上について DNA フィンガープリント法で真の親を同定した結果、つがい外の雄 によって授精されていた㮲は $3 \%$ に過ぎなかった（HASSELQUIST et al. 1995)。生涯に巣立たせた子 の数は、雄親では平均 10.5 羽、雌親では7.7羽だったが、雌雄とも個体差が大きく、次世代の雅の 50 \%を巣立たせたのは繁殖雄の17\%、雌の20\%の個体だった（Fig. 2 参照）。生涯に産み出した、成 鳥として定着できた子の数は、雄親当たり1.86羽、雌親当たり1.4羽だったが、やはり個体差が大き く、成鳥として定着した子の $50 \%$ 以が、17\%の雄、13\%の雌によるものだった（Fig. 3 参照)。 調査地生れの個体と移入個体とで、雅を巣立たせるのに成功したものの割合や子が成鳥として定着で きたものの割合には差はなく（Table 2)、生涯に巣立たせた雊数や成鳥として定着できた子の数に あ差はなかった (Figs. 2-3 参照)。これらの結果は、調査地に移入してきたオオョシキリが地域個 体群への新しい遺伝的素材をむたらすという点で重要な貢献をしていることを示唆する。

調查地の個体群では、 $r \geqq 0.25$ の近親個体間での繁殖例はなく、もっとも近かった 1 例はいとこ同

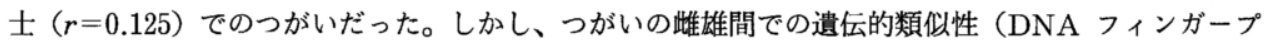
リントのバンドの共有率で測定）と粰化しない卵の割合との間に有意な正の相関が知られている (BENSCH et al. 1994)。これらのデー夕は、調查個体群では近親婚（incest）によらない同型交配 （inbreeding）が起こっていることを強く示唆する。この現象は創始者効果と個体群が小さいことに よって説明されるかむしれない。それに加えて、分散距離が短いという一般的傾向が、近隣個体群間 での大規模な個体の交流をもたらし（Fig. 4)、互いに高い遺伝的類似性をあつことで（BENSCH et al. 1994 参照)、近親婚によらない同型交配を促進してきた可能性むある。

\section{ヨシキリ属における配偶システムの進化}

(The evolution of mating systems in Acrocephalus warblers. 44 : 195-207)

CAtchpole, C. K.

School of Biological Sciences, Royal Holloway, University of London, Egham, Surrey TW20 OEX, U.K.

本論文ではヨシキリ属の配偶システムとその進化の考えられる筋道について概説する。これは LEISLER \& CATCHPOLE (1992) の総説をより新しくしたあのである。前著の発表以降、いくつかの 分野で重要な進歩や新発見があった。とくに DNA フィンガープリント法による最近の研究は従来 の知見に大きな衝撃をむたらしてきた。本論文ではまた、さえずりの進化に関する CATCHPOLE (1980，1987）による初期の研究をより新しいものに改め、さえずりの進化と配偶システムとの関係 について論じる。 
配偶システムは次のように分類する：

1. 単婚 (一夫一妻). 1 雄が 1 雌とつがう。

2. 複婚. 1 個体が複数の異性とつがう。

2a. 一夫多妻. 1 雄が複数雌とつがう。

2 b. 一妻多夫. 1 倠が複数雄とつがう。

2c. 乱婚. 雄・雌とあ複数の異性とつがう。

ヨシキリ属の配偶システムを Table 1 にまとめてある。表の下の種ほど単婚的で、上の種ほど、 単婚からはずれる度合いが大きくなる。セーシェルヨシキリA. sechellensis は最近になって研究 された種で（KOMDEUR 1992）、単婚だが協同繁殖種であある。ヨーロッパ産の多くの種は単婚だが、 最近になって社会的一夫多妻の例や DNA フィンガープリント法による、つがい外受精（EPFs） の証拠が報告されている（Table 1)。DNA フィンガープリント法は、一夫多妻性の 2 種間のきわ だった達いも明らかにした。オオヨシキリ A . arundinaceus のつがい外受精率は $3 \%$ と低いが、 ハシボソョシキリ A. paludicola では $36 \%$ と高く、スズメ目全体の中であもっとも高い種の 1 つ である。雛数の少ない巣ではすべての雊の父親は共通だが、雛数の多い巣では2-4雄によって受精さ せられている。同腹の雛の複数雄による受精は、ハシボソョシキリが例外的に乱婚的配偶システムを あつことを示唆する。

LEISLER \& CATCHPOLE（1992）は、昆虫食と両親での養育の必要性とによる環境上の制約から単 婚が生じたことを示唆した。ヨーロッパにおいては、「複婚を可能にする環境条件」は湿原の移行帯 で生じるだけであり、そこでは豊富な大型昆虫が片親での養育を可能にする。抱卵と雛への給餌にお ける雔雄間での分担のようすは Table 2 に示されている。協同繁殖するセーシェルヨシキリでは両 親が養育に参加するが、1 羽の雛を巣立たせるにはヘルパーの援助を必要とする。他の単婚の種では 両親が養育に参加し、複婚の種になって初めて、片親での養育がみられる。雄が養育から解放される 傾向は、雄がまったく養育に加わらないハシボソョシキリで頂点に達する。

配偶システムは形態上の特徵とも相関がみられる。複婚の種はより大きなくちばしをもち、より大 型の昆虫を慨にする。ハシボソョシキリでは精巣と総排泄腔突起が相対的に大きく、より多くの精子 を生産する。これらの特徴は、本種でみられる同腹の雛の複数雄による受精および例外的な乱婚的配 偶システムと関係するのだろう。

さえずりの構造と配偶システムの間にも明瞭な相関がみられる（Table 3)。CATCHPOLE（1980， 1987）が示唆したように、単婚の種は配偶者を引きつけるための長くて複雑なさえずりをあち、複婚 の種はなわばり防衛のための短くて単純なさえずりをむつ（Fig. 1)。最近の研究は、複婚の種が配 偶者誘引用の長いさえずりとなわばり防衛用の短いさえずりを別々にもつことを示している（Figs. $2 \& 3)$ 。 